\title{
FANATISME PENGGEMAR KPOP DALAM BERMEDIA SOSIAL DI INSTAGRAM
}

\author{
Asfira Rachmad Rinata, Sulih Indra Dewi \\ asfirarachmad@gmail.com,sulih_d@yahoo.com \\ Program Studi Ilmu Komunikasi Universitas Tribhuwana Tunggadewi Malang
}

\begin{tabular}{l} 
Article Info \\
\hline Keyword: \\
Korean Wave, Fans, Fanatism, \\
Instagram
\end{tabular}

\section{PENDAHULUAN}

Popularitas Gelombang Korean (Korean wave) atau yang lebih dikenal dengan Hallyu awalnya hanya bekembang di negara Asia Timur lalu menjadi populer diseluruh dunia hingga ke Indonesia (Jin, 2016). Perkembangan budaya Korea saat ini sangat populer dikalangan remaja dan dewasa baik perempuan ataupun pria usiabelasan tahun hingga tiga puluhan tahun. Kata Hallyu digunakan oleh Kementrian Budaya dan Pariwisata Korea Selatan saat merencanakan, memproduksi dan mendistribusikan kepingan CD musik dari musisimusisi Korea ke negara tetangga pada tahun 1999 atau dalam bahasa Inggris Korean pop Music (musik pop Korea), dalam bahasa Cina disebut juga dengan Hallyu - Song of Korea (Musik dari Korea). Istilah hallyu telah mendapatkan popularitas yang luas sejak surat kabar Cina memberitakan kesuksesan penyanyi Korea di Cina sebagai bagian dari Hallyu / Korean wave. Sebuah drama televisi Korea, What is Love All About disiarkan oleh saluran televisi Cina CCTV pada tahun 1997. Pada tahun berikutnya, saluran televisi Cina CCTV menyiarkan ulang serial ini di waktu tayang utama karena banyaknya permintaan untuk tayang ulang. Korean wave atau Hallyu memiliki produk yang beraneka ragam dari drama televisi (K-drama), Musik (K-pop) video-game dan makanan), Produk dan layanan Hallyu (pariwisata, produk kosmetik, bedah plastik, barang mode, dan layanan bahasa), saluran distribusi (berbagai platform media) (Choi, 2015 dalam Tae, 2017 : xii).

Korean wave dalam perkembangannya, juga memberikan dampak besar di dunia pertelevisian Indonesia.Karena televisi sebagai media informasi dan hiburan utama masyarakat Indonesia, salah satunya yakni Kdrama menjadi pilihan baru setelah serial drama India, Taiwan dan sangat populer melalui televisi. Masuknya K-drama ke Indonesia diawali dengan populernya dra- 
ma winter sonata di Indonesia. Selain itu, musik korea yang lebih dikenal dengan K-pop juga mengambil peran yang penting dalam mempopulerkan Korean wave di Indonesia. Musisi dan Grup Idola Korea Selatan silih berganti menggelar konser di Indonesia. Tahun 2011 hingga 2013 menjadi tahun-tahun meledaknya K-pop dan kedatangan bintang-bintang Kpop juga menjadi sorotan utama media di Indonesia.

Tersebarnya Korean wave melalui berbagai cara juga dipermudah dengan akses internet dan banyaknya media sosial yang memudahkan siapapun dapat mengakses informasi yang tersedia dalam berbagai bahasa. Keterbatasan akan perbedaan bahasa akhirnya juga dapat diatasi dengan makin banyaknya fans ataupun non-fans yang membuka jasa terjemah subtitle Kdrama atau pun Musik K-pop. Dengan begitu, orangorang yang menaruh minat pada budaya pop Korea Selatan akan semakin mudah dan semakin mencintainya. Akhirnya sebutan "Fans Korea" menjadi satu label bagi orang-orang yang menaruh minat pada segala bentuk budaya yang dibawa oleh Korea Selatan. Akun media sosial penggemar K-pop digunakan untuk mengakses berbagai informasi tentang idola mereka. Dikutip Dari survei kumparan, 56 persen fans K-pop menghabiskan waktu 1-5 jam berselancar di media sosial untuk mencari tahu segala informasi tentang idola mereka. Sebanyak 28 persen fans bahkan menghabiskan 6 jam lebih di dunia maya untuk melihat berbagai aktivitas sang idola (Kumparan, 2017).

Instagram merupakan situs jejaring sosial gratis kreasi dari Burbn, Inc yang memungkinkan penggunanya untuk mengambil foto, menerapkan filter digital, dan membagikannya ke berbagai situs jejaring sosial termasuk Instagram sendiri. Saat ini Instagram juga memungkinkan penggunanya untuk berbagi video pendek (Putri, 2015 : 75). Saat ini pengguna instagram semakin meningkat karena instagram mempunyai fitur yang sangat menarik dan merupakan situs jaringan sosial yang mempunyai aplikasi beragam, seperti chating, unggah foto dan video melalui snapgram, instastory. Selain itu, Pengguna juga dapat memilih untuk mengirimkan foto -foto kirimannya dengan menggunakan tanda pagar (\#) atau hastag untuk menampilkan lebih spesifik unggahan foto - foto ketika dicari dalam pen- carian aplikasi instagram (Bernadeta, 2017:95).

Melalui Instagram, penggemar K-pop melakukan sebuah aktivitas yang disebut dengan fanssgirling yakni sebutan yang digunakan untuk mendeskripsikan kegembiraan berlebih atau bahkan ekstrim terhadap kelompok idola tertentu. Fansgirling berasal dari kata fanssgirl dan Fans lelaki disebut dengan sebutan fansboy. Fansgirl dan fansboy sering dibedakan karena praktik tertentu yang mereka lakukan di dalam fandom (Jenkins, 2007). Penggunaan instagram untuk kegiatan fansgirling / fansboying menurut penggemar K-pop dikarenakan yang pertama kali dilihat adalah gambar dari idola. Penggemar lebih tertarik melihat gambar terlebih dahulu yang disuguhkan dari postingan Instagram Idola. Tak jarang juga jika penggemar K-pop menghabiskan waktunya di depan gawai selama berjam -jam untuk bermain media sosial dan berdiskusi dengan fandom mereka yang mengarah pada perilaku fanatisme. Menurut Joli Jenson, kelompok penggemar dihantui oleh citra penyimpangan. Penggemar (fans) selalu dicirikan sebagai suatu kefanatikan yang potensial. Terlebih kelompok penggemar juga dilihat sebagai perilaku yang berlebihan dan berdekatan dengan kegilaan. Jenson menunjukkan dua tipe khas patologi penggemar, "individu yang terobsesi” (biasanya lakilaki) dan "kerumunan histeris" (biasanya perempuan) (dalam Storey, 2010:157).

Fanatisme merupakan sebuah keyakinan terhadap objek fanatik yang dikaitkan dengan sesuatu yang berlebihan pada suatu objek, sikap fanatik ini ditunjukkan dengan aktivitas, rasa antusias yang ekstrem, keterikatan emosi dan rasa cinta dan minat yang berlebihan yang berlangsung dalam waktu yang lama (Eliani dkk, 2018 : 62). Dalam prosesnya, penggemar tidak lagi menjadi penonton untuk teks populer, akan tetapi mereka menjadi peserta aktif dalam membangun makna dari sebuah teks. McCudden menyebutkan bahwa aktivitas penggemar adalah membuat makna (meaning making), berbagi makna (meaning sharing), berburu (poaching), mengumpulkan (collecting) dan membangun pengetahuan (knowledge building) sebagai kegiatan utama yang relevan dengan aktivitas penggemar (McCudden, 2011:14) 
a. Membuat Makna (Meaning Making)

Penggemar terlibat secara aktif dalam membuat makna dan menginterpretasi dari teks media lalu menggabungkannya, sebagian atau keseluruhan, dengan pengalaman dan emosi kehidupan dari penggemar sendiri. Penggemar cenderung mampu mengevaluasi teks pada berbagai tingkatan sesuai kebutuhan mereka (Grossberg, 1992). Di sisi lain, Burke (2001) membuat perbedaan antara "penonton sosial" (social viewers) yang merupakan individu yang hanya mengonsumsi teks dan "penggemar" (fans) di mana penggemar secara kolektif menafsirkan teks dalam berbagai cara, dan menggunakannya untuk memahami dunia. Fiske (1992) menyebut jenis pemaknaan ini sebagai "produktivitas semiotik." Produktivitas semiotik, menurut Fiske, mengacu pada proses penggunaan teks media untuk membuat makna identitas sosial dan pengalaman sosial (dalam McCudden, 2011:15).

\section{b. Berbagi Makna (Meaning Sharing)}

McCudden (2011:15) menjelaskan bahwa penggemar dapat menggerakkan pikirannya mereka sendiri ke orang lain atau kedalam ruang bersama dari komunitas penggemar. Hal ini merupakan tindakan menggambil makna dari internal (dalam diri fans) dan membaginya ke lingkungan eksternal.

\section{c. Berburu (Poaching)}

Fiske (1992) menyebutkan bahwa produksi tekstual mengacu pada produksi teks yang diciptakan oleh penggemar (fanss).Fans secara pribadi memilih teks yang akan di proses sebagai dasar pembuatan creative project mengenai idola mereka atau yang disebut sebagai produktivitas tekstual. Jenkins (1992) merinci proses dalam produktivitas tektualbahwa fans mencontoh atau mengambil sebuah teks, menggunakan potongan teks tersebut untuk membuat cerita, dan menjadi ide kreasi mereka. Teks tersebut dapat berupa naskah televisi atau film, atau lirik lagu dari band tertentu, dan menggunakannya sebagai landasan untuk kegiatan kreatif mereka sendiri (dalam McCudden, 2011:17).

\section{d. Mengumpulkan (Collecting)}

Selain membuat makna, berbagi makna, dan berburu, mengumpulkan adalah bentuk keempat dari aktivitas yang dilakukan oleh penggemar (fanss). Pengumpulan dalam hal ini adalah praktik mengumpulkan barang-barang tertentu yang terkait dengan objek fandom yang digemari. Bagi penggemar, mengumpulkan sebanyak mungkin koleksi merchandise adalah menjadi sebuat tolak ukur koleksi penggemar, bukan dilihat dari nilai barang secara individu (Mc Cudden, 2011:21).

e. Membangun Pengetahuan (knowledge building)

McCudden (2011:21) menyebutkan kegiatan terakhir menjadi penggemar (fans) adalah membangun pengetahuan. Penggemar berusaha mengumpulkan pengetahuan mereka tentang objek yang menjadi fokus kegemaran.Pengetahuan dapat diambil dari berbagai bentuk tergantung pada jenis objek yang digemari dan preferensi individu dalam komunitas maupun sub-komunitas didalamnya. Kekuatan dari budaya penggemar berasal dari kekuatan pengetahuan yang dimiliki oleh penggemar tentang sejarah objek yang dikagumi.

Fiske (dalam Matt Hills, 2013: 132) menjelaskan tiga hal produktivitas penggemar mengenai teks di media sosial yang terkait dalam aktivitas penggemar yakni :

1. Produktivitas semiotik adalah ketika penggemar menggunakan objek fandom mereka untuk menciptakan makna sosial dalam kehidupan mereka sendiri. Contohnya adalah ketika Penggemar yang mendapatkan kepercayaan diri setelah melihat karakter favoritnya di televisi dan media sosial.

2. Produktivitas Enunciative (ucapan) adalah ketika penggemar mengekspresikan fandom (kelompok penggemar) mereka ke dunia luar melalui pidato atau penampilan. Contohnya Gaya rambut atau make-up, pilihan pakaian atau aksesori adalah cara membangun identitas sosial dan karenanya menegaskan keanggotaan seseorang dari komunitas penggemar tertentu (Fiske 1992: 38) (dalam Matt Hills, 2013: 132).

3. Produktivitas teks adalah ketika penggemar 
membuat teks berdasarkan objek fandom mereka. Produktivitas teks ini dapat membedakan sektor fandom dari audiens yang bukan penggemar. Di akun Fiske, sangat mungkin bagi yang bukan penggemar dan audiens biasa untuk berbicara tentang teks-teks media, sehingga berpartisipasi dalam produksi produktivitas Enunciative. Tetapi di era web 2.0, produktivitas teks - penciptaan fiksi penggemar (fans fiction), seni penggemar, ost film, dan video penggemar. Aktivitas ini membatasi komunitas penggemar dan identitas karena audiens yang bukan penggemar akan jauh lebih kecil kemungkinannya untuk terlibat dalam praktik produksi teks ini.

Terdapat sejumlah penggemar K-Pop yang memiliki kisah fanatisme yang tak biasa, seperti yang dikutip pada media online CNN Indonesia yakni Fans K-pop mulai dari mengejar idola hingga rela menginap satu hotel, rela mengeluarkan uang ratusan juta untuk membeli album demi berkesempatan mendapat tanda tangan idola, hingga merasa "tidur bersama idola" hanya karena terdapat poster yang mengarah ke tempat tidur. Sejumlah aksi fanssatisme K-Popers lainnya pun pernah terekam dalam pemberitaan, baik di Indonesia maupun di negara lain, mulai dari rela menunggu berjam-jam untuk menyambut kedatangan idola, hingga menyakiti diri sendiri kala idolanya meninggal dunia (CNN Indonesia, 2019).

\section{METODE PENELITIAN}

Penelitian ini menggunakan metode kualitatif deskriptif dengan fokus penelitian pada fanssatisme penggemar K-pop dalam bermedia sosial di Instagram serta bagaimana respon penggemar K-pop dalam menanggapi hoax dan informasi negatif tentang idola favorit.Teknik pengumpulan data yang digunakan adalah wawancara, dan observasi pada feed Instagram dan Instagram Story penggemar musik K-pop. Pemilihan informan menggunakan teknik purposive sampling.

\section{HASIL PENELITIAN}

Hasil penelitian menunjukkan bahwa perilaku Fanatisme penggemar tidak hanya terlihat dari seberapa jauh mereka menggemari idola Korea tetapi juga dalam bermedia sosial, hal tersebut terlihat dari berbagai aktivitas yang telah dilakukannya di Instagram serta respon fans K-pop dalam menyikapi informasi hoax dan negatif dari idola K-pop.

\section{Aktivitas Penggemar K-pop di Media Sosial Sebagai bentuk Fanatisme Pengemar}

Aktivitas penggemar yang berlebihan mengakibatkan seseorang menjadi fanatik terhadap sesuatu. Begitu pun juga dengan seorang penggemar Kpop yang sudah kagum dan gemar akan musik K-pop, mereka akan menghalalkan berbagai cara untuk dapat menikmati kegemarannya tersebut dan memproduksinya bahkan sampai mendistribusikannya melalui media sosial.

Dalam menunjang hobi fans K-pop, para fans banyak yang memiliki akun media sosial lebih dari satu akun, yang berfungsi untuk mencari tahu aktivitas sang idola dari berbagai media sosial dan juga digunakan untuk vote atau streaming project dari idola mereka. Hal tersebut juga membuat fans tergabung dalam kelompok atau komunitas tertentu dengan anggota yang memiliki minat terhadap idola yang sama atau yang biasa di sebut sebagai fandom. Fandom merupakan gabungan dari kata fans dan kingdom, yaitu sebuah komunitas besar penggemar idol Korea berkomitmen untuk mengkonsumsi produk terus menerus dengan melibatkan perasaan. Fandom memiliki forum khusus yang memungkinkan penggemar untuk melakukan interaksi atau sharing secara beramai - ramai melalui fanbase media sosial (Fauziah, 2015).

Aktivitas Pengemar seperti yang telah di jelaskan oleh McCudden bahwa pengemar K-pop saat ini tidak hanya sebagai penikmat gambar, video dan teks media yang diunggah idola korea di Instagram, namun mereka juga dapat mengintepretasikan dan membuat makna dari unggahan tersebut. Intepretasi Makna yang dibuat oleh fans K-pop berawal dari ketika idola Korea menggunggah foto / video/ teks di akun Instagram mereka. Seperti idola Korea juga menggunakan 
Instagram untuk mempromosikan dan memberikan informasi project yang sedang ia buat ke penggemar mereka. Postingan yang idola unggah sangat menarik perhatian fans K-pop dan tak jarang jika fans langsung tertarik dan menyimpan, mendownload bahkan mencapture postingan tersebut.
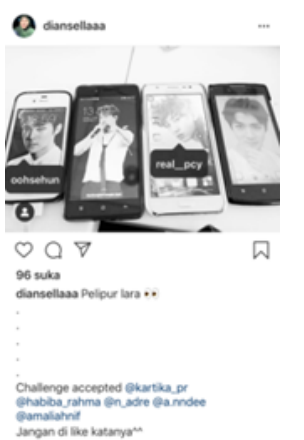

Sumber: akunIG@diansellaaa

Gambar 1 \& Gambar 2

Dari postingan tersebut, penggemar dapat memberikan banyak makna dan interpretasi dari unggahan idola mereka. Seperti ketika salah satu narasumber menggunggah koleksi gambar yang mereka screen capture dari Instagram idola lalu menggunggahnya lagi di akun Instagram pribadi dan memberikan caption yang sesuai dengan pengalaman serta emosi dan suasana hati fans. Dimana dalam gambar 1 pemilik akun (a)diansellaaa memaknai bahwa gambar yang ada di gawai adalah sebagai pelipur lara atau sebagai penyembuh rasa sakit karena tidak bisa bertemu dengan idola. Sedangkan jika dilihat dari gambar 2 dapat dimaknai bahwa idola yang berada dalam gambar tersebut memberikan semangat/ motivasi untuk lebih berkarya kepada fans. Pemaknaan yang di lakukan oleh fans tersebut merupakan salah satu aktivitas yang dilakukannya selama menjadi penggemar K-pop.

Fiske (dalam Matt Hills, 2013: 132) juga menjelaskan produktivitas yang dilakukan penggemar salah satunya yakni produktivitas semiotik dimana fans menggunakan gambar idola sebagai semangat untuk dirinya sendiri dan membagi pengalamannya ke pengikut akun IG@diansellaaa secara kolektif. Tak jarang fans lainnya juga melakukan hal serupa, yakni dengan memberikan makna serta menginterpretasikan gambar idola yang mereka unggah di akun IG. Perilaku pemaknaan terhadap secara kolektif iniketika sedang berada di dalam kelompok atau komunitas penggemar, salah satunya dapat dilihat dengan seberapa sering pengge- mar saling berdiskusi, bertukar informasi atau berdebat mengenai idola korea yang tidak diketahui oleh nonfans atau orang awam.

Pemaknaan memiliki dampak negatif dikalangan penggemar K-pop karena dapat menyebabkan Fanwar. Fanwar merupakan aktivitas perang fans/ penggemar di media sosial. Salah satu Fanwar yang pernah dilakukan oleh fans yakni antara fandom idol grup BTS (Army) dan fandom idol EXO (Exo -L). Penggemar yang fanatik tidak segan memberikan komentar pembelaan pada artis idolanya tanpa melihat bahwa artis idola mereka benar ataupun salah. Dan memberikan komentar negatif yang menjatuhkan artis idola lainnya pada unggahan atau berita tertentu. Hal tersebut terjadi karena berbagai faktor yakni seperti usia, terlalu fanatik akan suatu hal dan seringnya akun fansite di Instagram memberikan himbauan untuk menuliskan komentar yang positif bagi idola masingmasing.

Aktivitas lainnya yang dapat memperlihatkan perilaku fanatisme seorang fans K-pop yakni Berburu (poaching) dengan mencari sebanyak mungkin semua informasi mengenai semua idola mereka dari bagaimana kehidupan pribadi mereka, apa makanan - minuman favoritnya, playlist lagu favorit, foto terbaru idola, dan semua hal yang berkaitan dengan kesenangan dari idola mereka. Aktivitas ini membuat fans sangat aktif dalam mencari / berburu yang membuat mereka menghabiskan banyak waktunya untuk berselancar di dunia maya. Aktivitas tersebut dikatakan sebagai aktivitas stalking, menurut Cambride Dictionary merupakan aktivitas kejahatan mengikuti dan mengawasi seseorang secara ilegal selama periode waktu tertentu. Aktivitas stalking memiliki kecenderungan obsesif, yang berpotensi berbahaya. Banyak fans K-pop dan masyarakat yang tidak sadar jika kegiatan stalking dapat mempengaruhi kesehatan mentalnya.

Stalking yang dilakukan oleh fans K-pop tidak hanya di media sosial saja akan tetapi juga dikehidupan nyata mereka. Hampir semua fans K-pop cenderung telah melakukan stalking di media sosial. Jika tidak mendapat informasi mengenai idola di Instagram, maka fans mencarinya di Twitter, Facebook, SNS (Social Networking Service) yang hanya ada di Korea, akun Weibo (media sosial Cina) idola sampai pada orang 
terdekat idola sekalipun. Tidak hanya itu, dalam kehidupan nyata fans juga dapat melakukan stalking pada idola mereka. Aktivitas ini hanya dilakukan oleh fans yang ada di Korea ataupun fans non-Korea yang memiliki banyak modal untuk mengikuti semua kegiatan yang dilakukan oleh idola. Bahkan sampai membobol rumah idola, mencuri barang pribadi sampai pada memasang kamera pemantau dirumah idola, membobol akun media sosial sang idola serta berani menyewa hotel yang sama dengan tempat menginap idola.

Mencari informasi mengenai idola juga dilakukan oleh fans dengan cara mengikuti banyak akun Instagram fansite (fans yang sangat setia dan rela mengikuti idolanya kemanapun idolanya pergi, tidak hanya kettika didalam negeri bahkan sampai mengikuti jadwal idolanya diluar negeri) yang dibuat oleh fandom idola. Fansite merupakan situs, akun atau web penggemar yang dibuat oleh penggemar dan untuk penggemar/ fans. Aktivitas ini sangat menguntungkan penggemar ketika mencari informasi detail dan update kabar terbaru dari idola. Kebanyakan penggemar mengikuti akun Instagram fansite yang memiliki banyak gambar berkualitas HD dan kecepatan update berita idola. Memiliki akun fansite di Instagram sendiri juga dapat memberikan keuntungan bagi pengelola akun tersebut. Karena adanya pendapatan dari iklan dan donatur yang rela membayar mahal demi mendapatkan kualitas bagus foto, gambar, video sampai pada kabar berita idola.

Jenkins (1992) menyebut proses akhir dari "poaching" ini adalah text sebagai perantara penggemar dalam melakukan "poach", rekaman dan informasi untuk menciptakannya hasil tulisan sendiri, sebagai perantara produk dan komunitas. Banyak penggemar yang mencari semua informasi idola digunakan untuk karya mereka. Penggemar mencari dan memilih sendiri gambar, informasi idola yang dapat dibuat sebagai karya mereka dalam bentuk Fans Fiction, FMV (Fans Movie Video), Fans art (dalam McCudden, 2011:17).
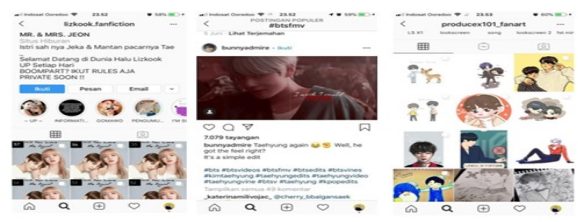

Sumber : akunIG@lizkook.fanssfiction, \#BtsFMV, @producex101_fanssart
Gambar 3. Fanss Fiction, Gambar 4. FMV, Gambar 5. Fanss Art

Jenkins (1992) menjelaskan bahwa penggemar / fans meminjam atau mengambil sebuah teks, menggunakan potongan-potongan tersebut untuk membuat cerita, dan menjadi ide kreasi mereka. Teks tersebut dapat berupa naskah televisi atau film, atau lirik lagu dari band tertentu, dan menggunakannya sebagai landasan untuk kegiatan kreatif mereka sendiri (dalam McCudden, 2011:17). Fansfic atau yang disebut fans fiction praktiknya praktik adalah mengambil teks yang ada dan menggunakannya sebagai titik awal untuk narasi kreasi penggemar, dengan tema yang sesuai keinginan dan pengalaman penggemar. Fanfic memiliki tujuan tertentu bagi penulis dan pembaca yakni kepuasan dalam berimajinasi. Seperti yang contoh pada gambar diatas, pengelola fanfic menuliskan deskripsi tentang fanfic yang ia buat yakni mengenai percintaan dari V BTS dan Lisa BlackPink. Padahal di dunia nyata karakter yang dituliskan dalam Fanfic tidak memiliki kedekatan hubungan. Karena dalam fanfic menurut Jenkins (1992) sendiri terdapat 10 tipe yakni, Recontextualization, Refocalization, Crossover, emotional intensification, genre shift, Character dislocation, moral realignment, Character dislocation, timeline expansion, eroticization. Dari semua tipe menurut Jenkins (1992) yang mendapat banyak penikmat yakni tipe eroticization, karena tak jarang jika penggemar memasangkan idola mereka dengan idola lainnya yang sesuai dengan tema yang mereka buat (dalam McCudden, 2011:19).

Untuk video creation yang dibuat penggemar atau yang lebih dikenal sebagai Fans Music Video (FMV), biasanya menggunakan rekaman yang sudah ada sebelumnya dari sebuah video, film atau acara televisi. Lalu Gambar-gambar tersebut, disusun dengan sengaja, menjadi bermakna yang memiliki kaitan satu sama lain, seringkali dengan cara yang berbeda dari pada teks aslinya. Aktivitas ini memungkinkan penggemar untuk berkreasi dengan tema atau plot yang mungkin tidak sesuai denga teks aslinya. Salah satu jenis video musik penggemar yang paling diminati oleh penggemar yakni jika dalam video asli dua karakter tidak terlibat hubungan romantis, penggemar akan 
mengatur/ mengeditnya menjadi dua karakter romantis (Ng, 2007 dalam McCudden, 2011:19)

Produktivitas teks ini merupakan efek yang timbul dari kegiatan mengonsumsi media sosial secara terus-menerus. Motivasi fans didasari atas pemenuhan kebutuhan psikologi dan emosi mereka. Selain itu produser mendapat kepuasan (satisfaction), serta kebutuhan akan penghargaan dan kebutuhan untuk mencari identitas serta kebutuhan akan pemenuhan diri. Hasil karya penggemar ini kemudian akan diunggah ke media sosial mereka untuk kemudian dibagikan/share dengan sesama penggemar K-pop. Tidak hanya sampai di situ, penggemar lainnya dapat turut memberikan feedback bagi creator; seperti meninggalkan komentar, kritik yang membangun sampai pada request produksi lainnya di akun media sosialnya.

Merchandise idola menjadi salah satu hal yang sangat populer dikalangan fans K-pop. Penggemar rela untuk mengantri dan mengikuti pre-order demi mendapatkan produk pertama kali. Pengumpulan merchandise ini merupakan salah satu bentuk aktivitas yang di lakukan oleh penggemar, yakni mengumpulkan (Collecting). Produk yang berkaitan dengan idola memiliki dua (2) sifat yakni resmi (official) atau yang tidak resmi (unofficial). Merchandise official yang idola berasal dari pihak manajemen artis yang menaunginya seperti light stick, album, baju, photocard, poster dll. Sedangkan produk unoffical idola diproduksi dari fans yang memiliki kreativitas dalam membuat design semua hal yang berkaitan dengan idola dan yang diproduksi ataupun tidak diproduksi oleh pihak manajemen artis akan diproduksi oleh fans demi keuntungan dan kesenangan fans K-pop lainnya. Hasil karya yang telah penggemar buat selama aktivitas berburu (poaching), juga banyak diminati oleh fans K-pop lainnya untuk mengumpulkan dan mengoleksinya.

Proses pengumpulan merchandise tidak hanya dapat dibeli di official store korea namun juga dapat dibeli melalui online. Banyak sekali akun instagram yang menjual merchandise official/unofficial seperti @ kpopsale dan akun Instagram online shop unofficial seperti yang dimiliki oleh salah satu informan yakni @ hallunation. Selain itu, merchandise unofficial dapat di peroleh dengan gratis jika fans hadir disuatu event atau konser yang mereka hadiri. Pengumpulan mer- chandise official / unofficial dilakukan oleh akun @diansellaaa dan@nisa_zy, mereka mengumpulkan koleksi merchandise dari idola secara berkala dan mengunggahnya di akun instagramnya.
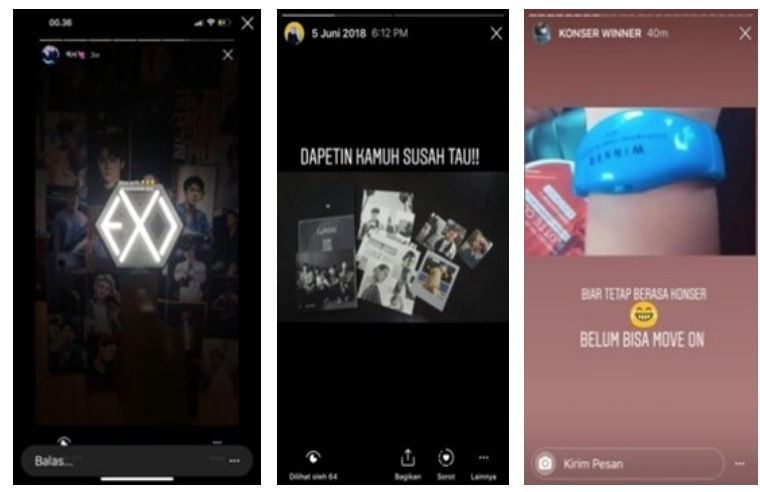

Sumber : akun Instagram@firarachmad, @diansellaaaa,@nisa_zy

Gambar 7.Unggahan ofc Album Idola di Ig Story, Gambar 8.Unggahan ofc Light Stick EXO di Ig Story, Gambar 9. Unggahan unofc gelang di Ig Story,

Bagi penggemar, mengumpulkan sebanyak mungkin koleksi merchandise adalah menjadi sebuat tolak ukur koleksi penggemar, bukan dilihat dari nilai barang secara individu (Mc Cudden, 2011:21). Semakin banyak koleksi merchandise yang dimiliki penggemar dapat mengekspresikan fandom (kelompok penggemar) mereka ke dunia luar melalui penampilan yang dibawakan oleh pengemar.

Contohnya saja gaya rambut atau make-up, pilihan pakaian atau aksesori adalah cara membangun identitas sosial dan karenanya menegaskan keanggotaan seseorang dari komunitas penggemar tertentu (Fiske 1992: 38) (dalam Matt Hills, 2013: 132). Tak jarang jika setiap fandom idola memiliki ciri khas sendiri mulai dari gradasi warna, font, logo, nama fandom dan juga terkadang usia penggemar turut mempengaruhi. Seperti contohnya idola K-pop Winner memiliki fandom Inner Circle dengan warna fandom Nebula Blue, BIGBANG dengan warna fandom Kuning dengan nama Crownstik serta dengan karakter pengemar yang sudah dewasa.

Mayoritas penggemar K-pop meggunakan media sosial Instagram untuk berinteraksi, mencari informasi, mencari gambar dan video, bertukar informasi terkait dengan idola dengan sesama penggemar lainnya di dunia maya walau belum pernah dilakukan 
tatap muka di antara keduanya. Di berbagai media sosial penggemar K-pop memiliki forum-forum khusus yang memungkinkan mereka untuk melakukan interaksi, berbagi informasi atau sharing secara beramairamai yang berlanjut pada social life atau kehidupan nyata mereka. Forum tersebut lebih dikenal penggemar K-pop dengan sebutan Fanbase. Fanbase merupakan sebuah wadah / grup dari sekumpulan penggemar K-pop yang memiliki kesamaan dalam menyukai / mengidolakan "idola K-pop" untuk mendiskusikan masing-masing idola dengan sesama penggemar. Fanbase di bentuk oleh penggemar K-pop dan diperuntukan juga bagi penggemar lainnya dengan tujuan untuk membangun pengetahuan (knowledge building) tentang idola mereka mulai dari data pribadi idola, aktivitas sehari-hari idola, project idola sampai pada fans project. Fans project ini ada ketika ada perayaan ulang tahun dari idola atau sedang mempromosikan lagu baru. Project ini biasanya berupa gathering disuatu tempat dengan memakai atribut dari fandom idola dan tak jarang jika fans project juga dilakukan di Korea dengan mengirimkan karangan bunga sebagai ucapan selamat untuk idola dalam pencapaian karirnya. Knowledge building atau membangun pengetahuan mengenai idola korea yang dibangun penggemar dalam Instagram dapat digambarkan dengan cara memposting gambar idola atau project yang telah dilakukan dan menandai atau men-Tag nama akun penggemar lainnya di salah satu postingan idola atau bahkan pada postingan informasi mengenai idola. Penandaan atau Tag yang terdapat dalam unggahan mengenai idola dapat memudahkan penggemar lainnya untuk langsung melihat postingan yang di maksud tanpa harus mencari di pencarian Instagram.

\section{Respon Penggemar}

Fanatisme penggemar K-pop selain ditunjukkan dari semua aktivitasnya di media sosial seperti Instagram, juga dapat ditunjukkan melalui respon penggemar dalam menanggapi informasi hoax dan negatif dari idola di Instagram mereka yakni, seperti ketika pertama kali akun Instagram berita seputar Kpop mengunggah postingannya yang berkaitan dengan hoax dan berita negatif idola, maka respon pertama kali penggemar ketika membacanya yakni bermacam- macam. Seperti kesal, kaget, sedih, marah, kecewa bahkan sampai pada sakit hati dan lemas. Respon terkait informasi dan pemberitaan hoax idola Korea tersebut juga bisa dipengaruhi oleh beberapa hal yakni salah satunya adalah usia penggemar, pengetahuan penggemar mengenai budaya K-pop, lingkungan, sampai pada kurun waktu menjadi penggemar K-pop.

Usia penggemar menjadi salah satu poin penting bagaimana penggemar merespon informasi hoax tentang idola mereka. Seperti halnya respon terkait informasi hoax idola di kalangan penggemar dengan rentang usia belasan tahun atau sekitar usia 12 - 17 tahun akan berbeda dengan responnya di kalangan penggemar usia $22-27$ tahun. Perbedaan tersebut terlihat dalam memberikan respon contohnya saja, ketika informasi hoax idola mulai ramai di Instagram tak jarang bagi mereka yang usianya masih cenderung ramaja memberikan komentar negatif dan tak jarang pula mereka langsung menandai teman sesama penggemar. Remaja memiliki kecenderungan besar menjadi penggemar fanatik yang tergabung dalam suatu komunitas penggemar yang disebut fandom, karena pada masa remaja rentan terpengaruh lingkungan sosial, dan dimana pada masa ini mereka lebih memilih mementingkan kepentingan kelompok dan teman sebaya (Jannah, 2014 dalam Eliani dkk, $2018: 67)$.

Sedangkan untuk usia yang matang seperti usia 22 - 27 tahun ketika merespon berita hoax, mereka akan mencari kebenarannya terlebih dahulu sebelum berkomentar lebih lanjut. Dikarenakan ketika penggemar K-pop yang mempunyai rentang usia $23-28$ tahun dengan pengalaman menjadi penggemar K-pop selama lebih dari lima tahun, maka reaksi yang di dapat adalah tetap tenang dengan mengamati pemberitaan melalui akun-akun besar Instagram berita K-pop atau pun melalui media sosial lainnya seperti twitter, SNS, ataupun Weibo Cina. Akan berbeda jika usia penggemar dibawah 20 tahun dengan pengalaman menjadi penggemar di bawah 5 tahun akan memberikan respon yang sedikit berlebihan seperti kesal, kecewa sampai dengan sakit hati yang diungkapkannya melalui media sosial. Tak jarang pula jika penggemar memberikan komentar pedas dan negatif di unggahan pemberitaan negatif yang di akun Instagram berita Kpop. 
Penggemar juga memiliki cara tersendiri untuk mencari kebenaran dari informasi hoax dan berita negatif dengan mencari konfirmasi kebenarannya dari berbagai sumber yang dapat dipercaya seperti akun official instagram idola K-pop, akun official Instagram dan website manajemen Idola, akun official Instagram TV lokal Korea seperti SBS, TVN, KBS dan MBC, serta situs berita besar korea seperti soompi.com, allkpop.com, naver.com. Sebagai contoh ketika situs hiburan Dispatch Korea merilis potongan gambar dan berita mengenai Kai EXO dan Jenny BlackPink berpacaran maka penggemar seketika itu langsung memberikan komentar di akun official Instagram idola dengan berbagai pertanyaan. Penggemar K-pop pasti sudah mengetahui situs hiburan Dispatch yang memang selalu menjadi paparazi bagi idola K-pop, oleh karena itu ketika munculnya berita yang bersumber dari Dispatch pasti beberapa Penggemar akan menyangsikan kebenaran berita tersebut sebelum pihak manajemen idola mengkonfirmasi kebenaran yang di beritakan oleh Dispatch dengan mengeluarkan press release ke media dan mengunggahnya ke berbagai akun media sosial manajemen idola. Selain itu faktor lingkungan penggemar pun tak luput juga dalam mempengaruhi penggemar ketika merespon informasi hoax tentang idola, yang mana lingkungan tersebut dapat berasal dari grup fanbase idola, teman sesama penggemar serta media sosial yang penggemar akses.

Saat ini dengan kemudahan akses internet dan berbagai macam platform media sosial seperti Instagram penggemar diberikan kemudahan untuk bisa mencari klarifikasi sumber berita dari situs yang dapat dipercaya. Terlebih jika mengenai pemberitaan idola Kpop. Akan tetapi tidak semua penggemar memiliki pemahaman yang baik bagaimana mencerna dan mencari kebenaran berita dari idolanya, dengan masih banyak yang mudah terpancing emosi seperti memberikan komentar jahat pada akun idola atau mengunggahnya di akun pribadi yang dapat memungkinkan memicu fanwar dengan penggemar lainnya.

Fanwar atau kegiatan perang antar fandom merupakan salah satu kegiatan fanatik dari pengemar K-pop yang masih menjadi perbincangan di berbagai media sosial tidak hanya di Instagram. seperti halnya Beberapa fandom besar di industri musil K-pop memiliki persaingan ketat satu sama lain, misal dalam tangga musik, penghargaan, maupun pengakuan publik. Selain itu diluar karir idola tak jarang penggemar juga melakukan fanwar karena masalah sepele yang bisa saja dipicu oleh pihak yang tidak bertanggung jawab yang kemudian akan memicu fanwar antar fandom.

Fanatisme yang ditunjukkan penggemar Kpop dalam bemedia sosial di Instagram secara tidak langsung dapat membentuk pola pikir, identitas dan kebiasaan mereka dalam bersosialisasi. Fanatisme penggemar K-pop juga cenderung asik sendiri dengan gawai mereka, seketika penggemar langsung membagikan temuannya yang ia dapat selama melakukan pencarian informasi dan berita dari idola korea yang di favoritkan kepada sesama penggemar melalui unggahan mereka.

Fanatisme yang terbentuk dengan adanya aktivitas dan respon yang penggemar berikan dapat membentuk rasa antusias, cinta dan keterikatan emosi berlebihan yang dimiliki oleh individu yang fanatik akan menimbulkan pemikiran bahwa hal yang mereka yakini merupakan hal yang paling benar adanya sehingga mereka akan cenderung untuk membela dan mempertahankan suatu kebenaran yang mereka yakini (Eliani dkk, $2018: 68$ ).

\section{KESIMPULAN}

Kesimpulan yang dapat diambil bahwa perilaku fanatisme penggemar dalam bermedia sosial tidak hanya dilihat dari sejauh mana dan berapa lama penggemar menjalani aktivitasnya sebagai penggemar K-pop, namun juga dapat dilihat dari respon mereka terhadap informasi Hoax dan berita negatif idola Kpop. Aktivitas penggemar ditunjukkan dari beberapa hal yakni pemberian makna, yang mana penggemar dapat dengan leluasa menginterpretasikan unggahan idola menurut emosi dan pengalamannya serta berbagi makna dengan penggemar lainnya. Seperti halnya merasa bangga kepada idola dan suntikan semangat diberikan idola ke penggemar melalui foto yang diunggah. Setelah aktivitas interpretasi makna penggemar melakukan "poaching" atau perburuan, perburuan yang dimaksud yakni mengikuti berbagai akun Instagram fansite idola, membuat fan fiction dan video kreasi penggemar dan dibagikan kepada penggemar K-pop 
lainnya. selain itu. Mengumpulkan merchandise dan mengunggah ke akun pribadi bagi penggemar K-pop adalah kebanggaan tersendiri karena memiliki salah satu koleksi dari idola. Aktivitas terakhir penggemar Kpop yakni berinteraksi dengan penggemar lainnya. Seperti bergabung dengan fanbase idola yang ditemui di Instagram dan saling menandai atau memberi komentar di setiap postingan yang diunggah oleh idola K-pop untuk memudahkan dalam pencarian informasi.

Fanatisme penggemar kpop juga ditunjukkan melalui responnya dalam menanggapi informasi hoax dan negatif dari idola mereka dengan berbagai macam respon seperti kesal, kaget, sedih, marah, kecewa bahkan sampai pada sakit hati dan lemas. Perasaan tersebut juga bisa dipengaruhi oleh beberapa hal yakni salah satunya adalah usia penggemar, pengetahuan penggemar mengenai budaya K-pop, lingkungan, sampai pada kurun waktu menjadi penggemar K-pop. Dan untuk mencari tahu kredibilitas informasi idola penggemar cenderung mencari klarifikasi kebenaran berita dari berbagai sumber yang dapat dipercaya seperti akun official instagram idol K-pop, akun official instagram management artis sampai pada media besar korea seperti soompi, allkpop.

\section{DAFTAR PUSTAKA}

Storey, John. (2010). Pengantar Komperehensif Teori dan Metode Cultural Studies dan Kajian Budaya Pop.Yogyakarta : Jalasutra

Tae Tae-Jin Yoon, Dal Yong Jin. (2017). The Korean Wave: Evolution, Fandom, and Transnationality. USA: Lexington Books.

Bernadeta, Lenny Setyowati. 2017. Aktualisasi Generasu $Y$ di Instagram. Jurnal Interaksi Universitas Diponegoro Semarang. Vol 6, No 1 (2017): January 2017. Hal: 95.

Eliani, Jenni M. Salis Yuniardi Alifah Nabilah Masturah. 2018. Fanatisme dan Perilaku Agresif Verbal di Media Sosial pada Penggemar Idola K-Pop. Jurnal Psikohumaniora: Jurnal Penelitian Psikologi, Vol 3, No 1 (2018), 59-72

Fauziah, Rizka, Diah Kusumawati. 2015. Fandom KPop Idol dan Media Sosial (Studi Deskriptif Kualitatif tentang Penggunaan Media Sosial Twitter pada Hottest Indonesia sebagai Followers Fanbase@taeckhunID, @2PMindohottest dan Idol Account@Khunnie0624). Skripsi. Digilib UNS - Fakultas ISIP Jur. Ilmu Komunikasi

Putri, Sukma Ari Ragil. 2015. Minoritisasi LGBT Di Indonesia: Cyber Bullying Pada Akun Instagram (a)denarachman. Jurnal Interaksi Universitas Diponegoro Semarang. Vol 4, No 1 (2015): January 2015. Hal: 75 .

McCudden, Michelle L. (2011). Degrees Of Fandom: Authenticity \& Hierarchy In The Age Of Media Convergence. Artikel.Doctor of Philosophy ofCommunication Studies Faculty of the University of Kansas. Kansas: U.S.A. P.

Matt,Hills. (2013). Fiske's 'textual productivity' and digital fandom: Web 2.0 democratization versus fanss distinction? . Participation Journal Of Audience \& Reception Studies, Volume 10Issue 1May 2013

CNN Indonesia.(2019). Bahaya di Balik Fenomena Candu K-Pop.Tersedia di https:// www.cnnindonesia.com/hiburan/20190202171900-227 -365989/bahaya-dibalik-fenomena-candu-k-pop Jenkins, Henry. (2007). Gender and Fanss Culture (Round Fifteen, Part Two: Bob Rehak andSuzanne Scott. Dalam Tersedia di http:// henryjenkins.org/2007/09/ gender and fanss culture round f $4 . \mathrm{html}$.

Kumparan. (2017). Fanatisme Fans K-Pop: Candu dan Bumbu Remaja. Tersedia di https://kumparan.com/ @ kumparank-pop/fanssatisme-fans-k-pop-candu-danbumbu-remaja

Definisi Stalking. https://dictionary.cambridge.org/ dictionary/english/stalking

Akun Instagram :

(a)diansellaaa

@firarachmad

@nisa_zy

@)lizkook.fanssfiction

(a)producex101_fanssart 
@kpopsale

@hallyunation

\#BtsFMV 